\title{
Globalization, Inequality, and Redistribution: Theory and Evidence
}

\author{
Giray Gozgor ${ }^{1} \quad$ Priya Ranjan \\ Dogus University, Istanbul University of California, Irvine
}

\begin{abstract}
This paper constructs a simple theoretical model to study the implications of globalization for inequality and redistribution. It shows that when globalization increases inequality, a policymaker interested in maximizing the sum of welfares of all agents increases redistribution. Empirically, the paper examines the effects of globalization on inequality and redistribution in a panel data set of 140 countries for the period from 1970 to 2012 . It finds that both inequality and redistribution have been increasing with globalization. The results are robust to the inclusion of many different controls and the exclusion of outliers.
\end{abstract}

Key Words: Globalization, Income inequality, Redistributive policies

JEL Classification Codes: F68, D63, H11

\footnotetext{
${ }^{1}$ Gozgor would like to acknowledge the grant of the Scientific and Technological Research Council of Turkey (TUBITAK), 2219 program.
} 


\section{Introduction}

A lot of empirical work has documented a significant rise in inequality across many countries over the last 35 years. Globalization and skill-biased technological change have emerged as the key factors responsible for the rising inequality. If globalization creates rising inequality, one would expect democratic societies to engage in redistribution to widely share the gains from trade. That is, one can expect globalization to lead to greater redistribution as well. However, globalization can also put constraints on the ability of the welfare state to redistribute. For example, a higher taxation could lead to a flight of mobile factors of production (skilled labor and capital), or increase distortion in the labor supply decision of higher earning factors such as skilled labor, which would reduce output and per capita income. This makes it interesting to study the relationship between globalization and redistribution, which is the subject of this paper.

To motivate the empirical work, we present a simple theoretical model with one sector, two factors of production- skilled labor and unskilled labor, and an imported input. Globalization is captured by a decrease in the price of the imported input. The policymaker chooses a tax-transfer scheme to maximize the sum of welfares of skilled and unskilled workers. Since skilled workers earn more, the optimal policy involves taxing skilled workers and transferring the proceeds to unskilled workers. The taxation of skilled workers distorts the supply of skilled labor, which acts as a constraint on the ability of the policymaker to redistribute. In this setting it is shown that globalization leads to an increase in inequality if the imported inputs can be easily substituted for unskilled labor. More interestingly, the policymaker redistributes more in response to the inequality increasing forces of globalization. It is further shown that the extent of redistribution can be measured by the difference between the pre-tax/transfer Gini coefficient of income and the post-tax/transfer Gini coefficient of income.

Our inequality and redistribution measures are obtained from The Standardized World Income Inequality Database (SWIID) of Solt (2014). The advantage of this dataset, according to Solt (2014), is that it "provide researchers with data that maximize comparability for the broadest possible sample of countries and years". We use the Gini coefficient of income as our measure of inequality. Solt (2014) provides data on pre-tax/transfer inequality called "market" income inequality and post-tax/transfer income inequality called "net" income inequality. We use the Gini coefficient of market income as our measure of inequality and the difference between the Gini coefficients of market income and net income as our measure of redistribution. An advantage of using this measure of redistribution is that it exactly corresponds to the share of redistributive taxation in total income in the theoretical model.

We use two alternative measures of globalization. First, trade openness is a quantitative measure of trade openness, measured as the sum of exports and imports relative to real GDP. We use both nominal trade openness and real trade openness ${ }^{2}$. Our main measure of globalization, however, is the KOF index of globalization which

\footnotetext{
${ }^{2}$ The latter is measured as the real exports plus real imports divided by real GDP where each variable is deflated by its own PPP
} 
is a composite of 3 indexes: Economic Globalization, Social Globalization, and Political Globalization. Our main interest lies in the index of Economic Globalization which consists of both outcome variables such as trade-GDP ratio, Foreign Direct Investment, Portfolio Investment and the policy variables such as tariffs, non-tariff barriers, capital account restrictions, etc. Unlike trade openness, the KOF index of globalization is multi-faceted and captures many different dimensions of globalization that could affect inequality and redistribution.

We verify that market income inequality has been increasing with nominal openness and the KOF index of globalization. The key result of the paper, however, is that the extent of redistribution has been increasing with globalization as well. While all 3 of the KOF indexes of globalization as well as the overall index are positively associated with redistribution, the relationship with the index of political globalization is not statistically significant. The results are robust to the inclusion of many different controls and the exclusion of outliers. Our alternative measure of globalization, both nominal and real trade openness, is positively (and statistically significantly) associated with redistribution as well. The results suggest that the redistributive policies by governments have ameliorated the impact of globalization on inequality.

The rest of the paper is organized as follows. In the next section we discuss the related literature. Section 3 presents the theoretical model. Section 4 describes the data used in the paper along with the empirical method used. Section 5 presents the empirical results. Section 6 provides various robustness checks. Section 7 provides concluding remarks.

\section{$2 \quad$ Related Literature}

In an influential paper, Rodrik (1998) argued that globalization made economies more vulnerable to shocks, and therefore, if agents are risk averse and the markets for insurance are missing, there would be a greater role for governments to mitigate risk through greater spending. It follows that the size of government would be positively associated with globalization. This implication was tested by Rodrik (1998) and many follow up studies by using the share of government consumption in GDP as a measure of the size of government.

However, stabilizing consumption or providing social insurance against risk is not the only role of government. The welfare state is deemed to have two key functions: social insurance and redistribution. While Rodrik (1998) focused on the former function of the welfare state in a globalized world, our focus is on the latter function. We argue theoretically and verify empirically that if globalization increases inequality in the distribution of income, then an inequality-averse government/policymaker (welfare state) redistributes more.

In the empirical work of Rodrik (1998) the extent of social insurance was proxied by the share of government consumption in GDP, called government size, while globalization was measured by nominal trade openness: the sum of imports and exports relative to GDP. He found trade openness to be positively associated with government

price index. 
size. Alesina and Wacziarg (1998) showed that country size (measured by population) was positively related with both government size and globalization, and therefore, could possibly account for the positive association between government size and globalization rather than there being a direct relationship between the two. Using country size as a control in the Rodrik (1998) regression framework, they found the result on the relationship between government size and globalization to be sensitive to whether the ratio variables (government size, openness) were entered in levels or $\operatorname{logs}^{3}$. Both Rodrik (1998) and Alesina and Wacziarg (1998) used cross-sectional data. Ram (2009) revisited the question using a panel data set for 154 countries over 41 years. Using fixed effects estimation which relies upon within country variation, Ram (2009) found the results to be supportive of Rodrik (1998), that is, even after controlling for country size, government size was positively associated with globalization.

All of these papers used the share of government consumption in GDP obtained from the Penn World Table (PWT) as a measure of the size of government. A recent paper by Jetter and Parmeter (2015) attempted to replicate the findings of Ram (2009) using more recent and different versions of the PWT datasets. They found the relationship between trade openness and government size to be sensitive to the choice of: i) the version of the PWT data set; ii) the time-frame; iii) the sample of countries; and iv) the way the key variables were entered in the regression (level or $\log$ ). Even though our focus is on redistribution, we also estimate the impact of globalization on government size using our version of PWT which is 8.1. Both nominal and real openness are positively related with government size, but the former fails to be statistically significant. What is more interesting for our purposes is that the correlation between government size and our measure of redistribution is a mere -0.054 . Clearly, our measure of redistribution is not just an alternative measure of government size.

Our main measure of globalization, the KOF index of globalization was developed by Dreher (2006a). Among the papers studying the impact of globalization on government size, Meinhard and Portrafke (2012) is the only paper that uses the KOF index as a measure of globalization. They found a positive relationship between the KOF index of social globalization and government size. In our sample, government size was significantly correlated only with the KOF index of political globalization, however, the sign was negative.

Among papers studying globalization and inequality, Dreher and Gaston (2008) examined the effects of the KOF indexes on the measures of income and wage inequality in 100 countries over the period 1970-2000. Their income inequality measure was the Gini index from the University of Texas Inequality Project (UTIP). They found a positive and significant effect of globalization on income inequality in the sub-sample of OECD countries. Bergh and Nilsson (2010) examined the impact of the KOF indexes on income inequality in 79 countries over the period 1970-2005 using the "net" income inequality measure from the Standardized World Income Inequality Database (SWIID) dataset of Solt (2009). They found that social globalization led to a higher income inequality

\footnotetext{
${ }^{3}$ When government size and openness were entered in levels, the relationship between government size and openness became insignificant after controlling for country size.
} 
and the effect was stronger in the low and middle income economies ${ }^{4}$.

Among other related research, some papers have studied the impact of some variables of interest on redistribution in addition to inequality. For instance, Morgan and Kelly (2013) examined how politics affected the market income inequality and redistribution in the Latin American and Caribbean countries. They used the same measure of redistribution that we use in this paper. They found that the market income inequality was more responsive to politics (left partisan power) than redistribution. Ostry et al. (2014) also used the same measure of redistribution in their study of the inter-relationships among income inequality, redistribution, and economic growth. They found a negative relationship between net income inequality and economic growth. They also found a positive association between market income inequality and redistribution, that is, societies with higher market income inequality tended to redistribute more. Dabla-Norris et al. (2015) confirmed the findings of Ostry et al. (2014) on the negative relationship between net income inequality and economic growth in a sample of 159 countries for the period 1980-2012. In addition, they also found there to be a negative but insignificant relationship between trade openness and income inequality (both market and net) in a sub-sample of 97 countries. They found the key drivers of inequality to be financial openness, financial development, less regulated labor markets, and technological progress.

To the best of our knowledge, there is no previous paper that theoretically shows a relationship between globalization and redistribution and empirically examines the effect of globalization on a comprehensive measure of redistribution that we use in the current paper.

\section{The Theoretical Model}

We construct a simple one sector model with an imported input that allows us to study the implications of globalization for inequality and redistribution. While globalization is normally studied in a multi-sector framework (for example the traditional two sector Ricardian or Heckscher-Ohlin model), our aim is to write down the simplest possible model that will do the job. Given the rising importance of input trade in world trade, the model below captures important elements of reality and delivers important empirical implications which are taken to data.

Suppose the model economy produces a single final good using the following production function:

$$
Z=\left(L^{\frac{\sigma-1}{\sigma}}+M^{\frac{\sigma-1}{\sigma}}\right)^{\frac{\sigma \gamma}{\sigma-1}} H^{1-\gamma}
$$

\footnotetext{
${ }^{4}$ There is a large literature on globalization and inequality and here we mention papers that use the KOF index of globalization. Among other related papers, Goldberg and Pavcnik (2007) investigated the distributional effects of globalization in developing countries. Schulze and Ursprung (1999) and Dreher (2006b) examined the globalization-welfare state nexus. See the recent survey article by Portrafke (2015) for these and several other related papers.
} 
where $L$ is unskilled labor, $H$ is skilled labor and $M$ is an imported input. The elasticity of substitution between unskilled labor and the imported input is $\sigma$ while the elasticity of substitution between the composite of unskilled labor and imported input and skilled labor is unity. Below we are going to focus more on the interesting case where $\sigma>1$ in which case globalization (decrease in the price of imported inputs) will increase inequality and induce the policymaker to redistribute more.

While unskilled workers supply one unit of labor inelastically, the supply of skilled labor is elastic. Denote the number of unskilled workers by $L$ which also means that the total amount of unskilled labor in the economy is $L$. Suppose the number of skilled workers in the economy is $N_{h}$, and their utility function is given by

$$
u_{h}\left(c-\alpha h^{2}\right) ; u_{h}^{\prime}>0, u_{h}^{\prime \prime}<0
$$

where $c$ is consumption of the single final good $Z$ and $h$ is the hours supplied by skilled workers. They get disutility from work which is captured by the convex cost of effort function $\alpha h^{2}$, expressed in units of the consumption goood, where $\alpha>0$. Now, if the skilled wage is $r$ and the tax on the hourly wage is $T$ then the skilled workers choose their hours optimally as follows.

$$
\underset{h}{\operatorname{Max}}\left\{u_{h}\left((1-T) r h-\alpha h^{2}\right)\right.
$$

The first order condition for this maximization implies

$$
h=\frac{(1-T) r}{2 \alpha} .
$$

That is, the higher the tax the lower the supply of skilled labor. This acts as a constraint on the ability of the policymaker to tax skilled workers.

The utility function of unskilled workers is $u_{l}(c)\left(u_{l}^{\prime}>0, u_{l}^{\prime \prime}<0\right)$ where $c=w+s$ where $w$ is the unskilled wage and $s$ is the amount of transfer they receive. The government runs a balanced budget and therefore, the transfer per unskilled worker is

$$
s=\frac{\operatorname{Trh}}{L} N_{h}
$$

The policymaker's objective function is given by

$$
N_{h} u_{h}\left(c-\alpha h^{2}\right)+L u_{l}(c) .
$$

That is, the policymaker simply maximizes the sum of utilities of all agents.

The firms, workers, as well as the policymaker take $w$ and $r$ as given in their maximization. The policymaker announces a tax rate $T$ and then skilled workers choose their hours optimally anticipating a skilled wage $r$. Therefore, the policymaker recognizes the impact of its choice of $T$ on the choice of $h$ by skilled workers given by (1). The policymaker solves the following maximization problem.

$$
\operatorname{Max}_{T}\left\{N_{h} u_{h}\left((1-T) r \frac{(1-T) r}{2 \alpha}-\alpha\left(\frac{(1-T) r}{2 \alpha}\right)^{2}\right)+L u_{l}\left(w+N_{h} \frac{T r}{L} \frac{(1-T) r}{2 \alpha}\right)\right\}
$$


Simplify the above to obtain

$$
\underset{T}{\operatorname{Max}}\left\{N_{h} u_{h}\left(\frac{((1-T) r)^{2}}{4 \alpha}\right)+L u_{l}\left(w+\frac{N_{h}}{L} \frac{(1-T) T r^{2}}{2 \alpha}\right)\right\} .
$$

The first order condition from the above maximization is given by

$$
-N_{h} u_{h}^{\prime} 2(1-T) \frac{r^{2}}{4 \alpha}+N_{h} u_{l}^{\prime} \frac{r^{2}}{2 \alpha}(1-2 T)=0
$$

The above implies

$$
\frac{(1-T)}{(1-2 T)}=\frac{u_{l}^{\prime}}{u_{h}^{\prime}}
$$

Note from above that the policymaker is not going to equalize the incomes of skilled and unskilled workers completely. Since the taxation causes a distortion in the supply of skilled labor, the optimal redistributive taxation will lead to $u_{l}^{\prime}>u_{h}^{\prime}$. That is, unskilled workers are going to be poorer than skilled workers.

If the preferences of workers are logarithmic, then we get the following.

$$
\frac{(1-T)}{(1-2 T)}=\frac{((1-T) r)^{2}}{4 \alpha\left(w+\frac{N_{h}}{L} \frac{(1-T) T r^{2}}{2 \alpha}\right)} .
$$

The above gives $T$ as a function of $w$ and $r$. Re-write the above as

$$
\left(4 \alpha w+2 \frac{N_{h}}{L}(1-T) T r^{2}\right)=\lambda(1-2 T)(1-T) r^{2} .
$$

Since each skilled worker supplies $h$ hours of labor given by (1), the amount of skilled labor available for use in production is given by

$$
H=N_{h} h=N_{h} \frac{(1-T) r}{2 \alpha} .
$$

Denote the price of the imported input by $\phi$. The firms undertake the following profit maximization exercise.

$$
\underset{L, M, H}{M a x}\{Z-w L-\phi M-r H\}
$$

Using the definition $\digamma \equiv\left(L^{\frac{\sigma-1}{\sigma}}+M^{\frac{\sigma-1}{\sigma}}\right)^{\frac{\sigma \gamma}{\sigma-1}-1} H^{1-\gamma}$, the first-order conditions are given by

$$
\begin{aligned}
& L: \quad \gamma A \digamma_{L} L^{\frac{-1}{\sigma}}=w, \\
& M: \quad \gamma A \digamma_{L} M^{\frac{-1}{\sigma}}=\phi, \\
& H \quad: \quad(1-\gamma)\left(L^{\frac{\sigma-1}{\sigma}}+M^{\frac{\sigma-1}{\sigma}}\right)^{\frac{\sigma \gamma}{\sigma-1}} H^{-\gamma}=r .
\end{aligned}
$$

The 5 equations (7), (8), (9), (10), (11) determine the 5 endogenous variables of interest: $w, r, T, M$, and $H .^{5}$

\footnotetext{
${ }^{5}$ Note that to save on notation we are using $H$ for both the firm choice of skilled labor and the supply of skilled labor. What really happens is that the firm's choice of skilled labor is given by (11) which must equal the supply of skilled labor given in (8) in a competitive equilibrium.
} 
Since our aim lies in studying the impact of globalization on inequality and redistribution, a natural question to ask is what is a good measure of redistribution? Since all taxation is redistributive in our model, a simple measure of redistribution is the amount of tax revenue relative to factor income:

$$
\text { Redist }=\frac{r T h N_{h}}{r h N_{h}+w L} .
$$

Below we verify that the above measure of redistribution exactly corresponds to the difference between the pretax Gini coefficient of income and the post-tax Gini coefficient of income. Since there are only two levels of income, the pre-tax Gini coefficient of income is given as follows.

$$
G_{g}=\frac{r h N_{h}}{r h N_{h}+w L}-\frac{N_{h}}{N_{h}+L} .
$$

Similarly, the post-tax Gini coefficient of income is given by

$$
G_{n}=\frac{r(1-T) h N_{h}}{r(1-T) h N_{h}+(w+s) L}-\frac{N_{h}}{N_{h}+L} .
$$

It is easily verified (upon using (2)) that the difference between the two, which we call redistribution, $R$, is given by

$$
R=G_{g}-G_{n}=\frac{r T h N_{h}}{r h N_{h}+w L} .
$$

That is, the difference between the pre-tax Gini and the post-tax Gini exactly corresponds to the share of redistributive taxation in income as given in (12).

Next, we want to study the impact of globalization on inequality, $\frac{d G_{g}}{d \phi}$, and redistribution, $\frac{d R}{d \phi}$. It is clear from the model that they, in turn, depend on the signs of $\frac{d r}{d \phi}, \frac{d w}{d \phi}$, and $\frac{d T}{d \phi}$. We can use the 5 equations (7), (8), (9), (10), (11) to do these comparative statics, but doing so in the general model above is quite complicated. Therefore, we are going to solve it numerically, but to gain some intuitive insights, we are going to look at a special case below.

\subsection{Special Case}

Suppose skilled workers also supply one unit of labor inelastically. In this case the amount of skilled labor available is given by $H=N_{h}$. The utility function of the two types of workers is identically given by $u(c)$ with $u^{\prime}(c)>0, u^{\prime \prime}(c)<0$. In this special case, equations (9)- (11) determine $w, r$, and $M$. The following comparative static result is verified in this case (proof in appendix).

Result 1: $\frac{d(r / w)}{d \phi}<(>) 0$ if $\sigma>(<) 1$.

That is, wage inequality increases with globalization if unskilled labor and imported inputs can be substituted easily; and this is the case we are going to focus on below.

Since the taxation doesn't cause any distortion in the labor supply of skilled workers, in this case the policymaker simply equalizes the incomes of the two types. That is $T$ is such that

$$
r(1-T)=w+s .
$$


From the balanced budget constraint, we get

$$
T=\frac{r / w-1}{r / w} \frac{L}{L+N_{h}}
$$

That is, $T$ is increasing in the inequality $r / w$. It follows from Result 1 that when $\sigma>1, \frac{d T}{d \phi}<0$. That is, the rate of taxation increases with globalization. To see how this translates into the difference between pre and post tax Gini, note that the pre-tax Gini in this special case is

$$
G_{g}=\frac{r N_{h}}{r N_{h}+w L}-\frac{N_{h}}{N_{h}+L}
$$

The post tax Gini is zero because the policymaker equalizes the incomes of the two groups. Therefore, $R=$ $G_{g}-G_{n}=G_{g}$. Verify from above that

$$
\frac{d R}{d \phi}=\frac{d G_{g}}{d \phi}=\left(\frac{L N_{h}}{\left(\frac{r}{w} N_{h}+L\right)^{2}} \frac{d\left(\frac{r}{w}\right)}{d \phi}\right) .
$$

That is, the sign of $\frac{d R}{d \phi}$ depends on $\frac{d\left(\frac{r}{w}\right)}{d \phi}$. Therefore, when $\sigma>1$ Result 1 above implies that $\frac{d R}{d \phi}<0$. That is, in this special case, we can show analytically the result that both inequality and redistribution increase with globalization.

Below we show this result numerically for the more general case.

\subsection{General Case}

In the general case, we cannot provide analytical solutions, but we verify numerically that when $\sigma>1$ we get $\frac{d G_{g}}{d \phi}<0$ and for the $R$ given in (15) we get $\frac{d R}{d \phi}<0$.

Parameters for the Numerical Example: $A=1 ; L=1 ; N_{h}=1 / 4 ; \gamma=2 / 3 ; \sigma=1.5 ; \alpha=0.1 ; \phi \in[0.5,1.5]$.

Figure 1a shows how $G_{g}$ increases with globalization (as $\phi$ decreases). Figure 1b shows how the endogenous response of the policymaker leads to increased redistribution, $R$, with globalization. Extensive numerical simulations confirm that the results are robust and do not depend on the specific parameters chosen for the numerical example in figure 1 . The key results of the paper are summarized below.

Result 2: $\frac{d G_{g}}{d \phi}<(>) 0$ and $\frac{d R}{d \phi}<(>) 0$ if $\sigma>(<) 1$.

Before moving to the next section, it is worth mentioning that the results derived here on the implications of globalization for inequality and redistribution can also be derived in a standard two sector Heckscher-Ohlin model with two factors of production: skilled labor and unskilled labor. Our one sector framework makes the derivation of optimal redistribution analytically more tractable.

Having seen the theoretical motivation for studying the relationship between globalization, inequality, and redistribution, we turn to the empirical exercise next. 


\section{Empirical Model, Data, and Econometric Methodology}

\subsection{Empirical Model}

Our two key estimating equations are based on Result 2 derived from the theoretical model. In particular, we estimate the following two equations.

$$
\begin{gathered}
\text { Inequality }_{i t}=\alpha_{0}+\alpha_{1} \text { Globalization }+\alpha_{2} X+v_{t}+v_{i}+\varepsilon_{i t} ; \\
\text { Redistribution }_{i t}=\alpha_{0}+\alpha_{1} \text { Globalization }+\alpha_{2} X+v_{t}+v_{i}+\varepsilon_{i t} .
\end{gathered}
$$

Inequality $_{i t}$ is the Gini index of market income and Redistribution ${ }_{i t}$ is the difference between the Gini index for market and the Gini index for net income. Globalization is going to be captured by KOF index of globalization as well as the nominal and real trade openness defined earlier. $X$ is a vector of controls and, $v_{t}, v_{i}$, and, $\varepsilon_{i t}$, respectively, denote the "time effect", the "country effect", and the "error term".

Our choice of controls is informed by the existing literature on the subject. In our benchmark model we use $\log$ real GDP per capita and the age dependency ratio as the controls. Later we assess the robustness of our results to some other controls used in the literature such as population, human capital, urbanization, quality of institutions etc.

Our approach of running fixed effect regressions is standard in the literature (see for example, Dreher and Gaston, 2008; Bergh and Nilsson, 2010; Ostry et al., 2014). We use robust standard errors clustered at the country level and run the cluster-robust Hausman test of Kaiser (2014) to assess the validity of our fixed effect estimation. As pointed out by Kaiser (2014), when robust standard errors are clustered at the cross-sectional level in the fixed effects estimations, the classical Hausman test has size distortions. Therefore, we consider the recent Hausman test technique of Kaiser (2014). This technique corrects for the size distortion in the Hausman test when robust standard errors are considered.

\subsection{Data}

The time period of our data is from 1970 to 2012. Our key measure of globalization, the KOF index of globalization, is obtained from the database of the Swiss Federal Institute of Technology, Zurich ${ }^{6}$. Among the three KOF indexes, the index of economic globalization is available for the least number of countries. This is our main index of interest because it is closely tied with the motivating theoretical model and we have a better understanding of the implications of economic globalization for inequality and redistribution than of social and political globalization. Therefore, we restrict our empirical exercise to those country-year pairs for which the

\footnotetext{
${ }^{6}$ The beginning date of KOF globalization data set is 1970, and that's why the starting period of our empirical exercise is the year of 1970 .
} 
KOF index of economic globalization is available ${ }^{7}$. We provide details on the KOF index of globalization in the data Appendix I. Our alternative measure of openness is the trade-GDP ratio. We use two variants of it: Nominal openness and Real openness. Nominal openness is the traditional variant which is constructed using nominal values of exports, imports, and GDP. Alcala and Ciccone (2004) argued that the nominal openness overstates the importance of trade for poor countries compared to rich countries due to huge differences in the prices of non-traded goods. Following their reasoning, we use real trade openness measured as the sum of real exports and real imports relative to the real GDP as an alternative measure of trade openness ${ }^{8}$. The data for both nominal and real openness are obtained from PWT version 8.1 as are the data on government size (measured by the share of government consumption in GDP).

The data on income inequality and redistribution come from the SWIID (version 5.0) of Solt (2014). As mentioned in the introduction, the measure of redistribution is the difference between the Gini coefficient of pretax/transfer income and the Gini coefficient of post-tax/transfer income. An advantage of this derived measure of redistribution is that it is available for a much larger number of countries compared to the standard measures of redistribution used in literature. For example, information on subsidies and social expenditures tend to be available for mainly OECD countries. Also, as shown by Ostry et al. (2014), the correlation between this measure of redistribution and the ones used in the literature vary from 0.42 to 0.7 (see Table 1 in their paper). This may be due to the fact "that many presumptively redistributive transfers may not be so in particular cases" (Ostry et al. 2014). As well, this measure of redistribution is closely tied to the share of redistributive taxation in GDP in the theoretical model, and it is hard to get a direct empirical measure of the share of redistributive taxation in GDP.

The details on the other controls used in the paper as well as the descriptive statistics on all variables are provided in Table 1. The correlation matrix for the key variables used in the regressions is provided in Table 2.

\section{$5 \quad$ Empirical Results}

\subsection{Results from benchmark regressions}

Tables 3 and 4 present the results of the benchmark regressions with the Gini index of market income and redistribution as the dependent variables. Following Berg and Nilsson (2010) and many others, the data are

\footnotetext{
${ }^{7}$ This allows us to have the same countries in the regressions involving different KOF indexes as well as the overall index facilitating comparison.

${ }^{8}$ Note that Alcala and Ciccone (2004) actually use nominal exports plus imports over real GDP as their measure of real openness because they didn't have access to price indexes for exports and imports. Since the introduction of PPP for exports and imports in PWT 8.0, it is possible to use real exports and real imports in constructing real openness which is what we do using the PWT version 8.1 of Feenstra et al. (2015).
} 
averaged over 5 year intervals to prevent short term fluctuations affecting results ${ }^{9}$.

The results for nominal and real trade openness are in columns 1 and 2, respectively, while the results for the KOF globalization indexes (economic, social, political, and overall) are reported in columns 3, 4, 5, and 6, respectively. All measures of globalization increase inequality, but the coefficient of real trade openness is not statistically significant. More importantly, as shown in Table 4, all measures of globalization increase redistribution, but the coefficient of the index of political globalization is statistically insignificant. That is, greater globalization is associated with higher redistribution. To get a sense of the magnitudes of these effects, looking at the economic globalization index, we find that a one standard deviation increase in this index implies a 3.49 points increase (0.43 standard deviation) in market income inequality, and a 1.36 points increase (0.21 standard deviation) in redistribution. The corresponding numbers for the overall KOF Globalization Index are of similar order of magnitude.

Among the controls, both the per capita income and age dependency ratio are positively associated with both inequality and redistribution. Finally, the cluster-robust Hausman test (Kaiser,2014) performed on the estimations in tables 3 and 4 verify that the OLS fixed effect estimations are consistent.

Our result that economic and social globalization indexes are positively associated with income inequality is consistent with the findings of Bergh and Nilsson (2010). The novel finding of our paper is the positive relationship between globalization and redistribution.

While our measure of redistribution is the difference between market and net income inequality, we also examine the relationship between government size and globalization, a much studied issue in the literature. As mentioned earlier, government size in these studies is measured by the share of government consumption in GDP. The results on the relationship between government size and globalization for our sample are reported in table 5. Government size is positively associated with nominal and real trade openness, but the coefficient of nominal openness fails to be statistically significant. As first noted by Alcala and Ciccone (2004), nominal trade openness overstates the extent of globalization for poor countries, and if the relationship between globalization and government size is stronger for rich countries, then we should expect a stronger relationship between real trade openness and government size than between nominal trade openness and government size. The result on the positive association between government size and openness is consistent with the result in Rodrik (1998) and Ram (2009). Among the KOF indexes of globalization, only the index of political globalization is significant but its sign is negative suggesting that greater political globalization leads to smaller government size. These results are different from Meinhard and Portrafke (2012) who find a positive relationship between the KOF index of globalization and government size. However, given the findings of Jetter and Parmeter (2015) regarding the sensitivity of the relationship between globalization and government size, it is not surprising that our results

\footnotetext{
${ }^{9}$ Since we have 43 years of data, and we wanted to have last 5 years (2008-12) separate as the post financial crisis years, our first two data points are 4 year averages and the rest are 5 year averages: 1970-73, 74-77, 78-82, 83-87, 88-92, 93-97, 98-02, 03-07, 08-12.
} 
based on a different dataset differ from Meinhard and Portrafke (2012). More importantly, while government size may be a good proxy for capturing the extent of social insurance provided by the government, it is not likely to be good at capturing the extent of redistribution by the government. This is also borne out by the fact that the correlation between government size and our measure of redistribution is -0.054 . This gives us confidence that our measure of redistribution is not simply a proxy for government size.

Having looked at the benchmark regressions and compared our results with the existing literature on government size and globalization, we provide a host of robustness exercises below.

\section{Robustness Checks}

\subsection{Countries at different Levels of Economic Development}

Our first robustness exercise is to see if our results differ according to the level of development of countries. For this purpose, we divide our sample into two groups: High income and Low income. We use the World Bank (2015) classification of the country and lending groups according to which our sample of high income countries includes countries with per capita income greater than $\$ 4125$ in 2014 (84 countries) while low income countries are those with per capita income below this amount (56 countries). The details of the classification are reported in the data appendix II.

Table 6a reports results for the low income countries and table $6 \mathrm{~b}$ reports results for the high income countries. We find that the positive relationship between globalization and inequality as well as between globalization and redistribution is driven primarily by the high income countries. Even though the index of economic globalization is positively associated with inequality in low income countries, it doesn't lead to greater redistribution.

\subsection{Results with Balanced Panel}

Since our panel dataset with 140 countries is unbalanced with only a few observations for some countries, tables 7 and 8 present the results of the benchmark regression with a balanced panel. The sample size is much smaller with only 42 countries and 378 observations. The results with the KOF indexes of globalization are similar to those for the benchmark regressions. All of the indexes are positively associated with the coefficients being statistically significant. As was the case in table 4, the KOF indexes except for the index of political globalization are positively associated with redistribution with the coefficients being statistically significant. Both the trade openness measures are positively associated with inequality and redistribution, but the coefficients are not statistically significant. 


\subsection{Results with annual data}

Our next robustness check involves running benchmark regressions with annual data and the results are reported in tables 9 and 10. The only difference from the regressions reported in tables 3 and 4 is that instead of using the current value of the globalization variables we use one year lagged value of it. This is to alleviate the problem of reverse causality affecting the estimates as is highlighted by Portrafke (2015). The results for the KOF indexes of globalization are qualitatively similar to those obtained in the benchmark regressions in tables 3 and 4 . The results, however, are different for trade openness measures. Even though both measures of trade openness are positively associated with inequality and redistribution, the coefficients are not statistically significant.

\subsection{Robustness to the inclusion of other controls}

Recall that our benchmark model includes the log real GDP per capita and the age dependency ratio as controls. Our next set of robustness checks involves adding other controls commonly used in the related literature. The results are reported in tables 11 and 12. Rather than adding all these controls at the same time, we first add the controls in such a way that our estimating equation becomes comparable to the benchmark regression in another paper. When we add log population as a control to our benchmark regression, the estimating equation becomes the benchmark regression in Meinhard and Portrafke (2012). When we add the level of human capital to our benchmark regression, our estimating equation becomes the benchmark model of Bergh and Nilsson (2010). When we add the urbanization rate to our benchmark regression, our estimating equation becomes the benchmark regression in Rodrik (1998). The results of this exercise are reported in the top half of table 11. To facilitate comparison we also present the results of our benchmark regression at the top of table 11. It is easily verified that the results for the KOF indexes of globalization are robust to the inclusion of these controls. As was noted in the regressions with annual data and balanced panel, the coefficients of trade openness always have the positive sign but are not always statistically significant.

We also consider various measures of institutional quality which can affect the level of income inequality and redistribution. In particular, following Bergh and Nilsson (2010), we add the civil liberties index from the freedom in the world database; following Dreher and Gaston (2008) we add the democracy index from the Polity IV data set; following Rodrik (1998) we add an index of overall institutional quality based on the constraint on the executive power from the Polity IV data set. Following Rodrik (1998), we consider the consumer price linked inflation rate as a potential control because inflation is like a tax and also has redistributive implications. Finally, following Rodrik (1998) we also use the diversification of exports as a control. The idea behind this control in Rodrik (1998) is that countries with more diversified export baskets are less vulnerable to external shocks and therefore, there is less need for governments to provide protection against external shocks. Note that this argument is less compelling for redistribution which is our focus, but we do this anyway as a robustness 
exercise. The results in all these cases show a pattern similar to the one observed in the previous paragraph. The results for the KOF indexes of globalization are robust, but not for the measures of trade openness.

\subsection{Robustness to outliers}

Our next set of robustness exercises involves excluding extreme observations for inequality, redistribution, and measures of globalization. Following Bergh and Nilsson (2010), we define the extreme observations as those which are more than two standard deviations away from the average. Again, as shown in table 12, the results are robust when globalization is measured by the KOF indexes, but not necessarily for openness to trade.

Rodrik (1998) contends that the effect of globalization on government size can be region-specific, and therefore, he uses the region-specific dummies for Latin America, East Asia, and Sub-Saharan Africa countries in his crosssectional data estimations. Since we have a panel data where we use country fixed effects, we cannot use regional dummies. Following the spirit of the exercise in Rodrik (1998), Bergh and Nilsson (2010) separately exclude the observations for the Latin America, developing East Asia, and the Sub-Saharan African countries to see the robustness of their findings. We follow Bergh and Nilsson (2010), and re-estimate our benchmark regressions by excluding observations from Latin America and the Caribbean, East Asia, and Sub-Saharan Africa, one region at time. The results, shown in table 12, are robust to the exclusion of these regions for the KOF indexes of globalization but not necessarily for trade openness. In other words, our results in the benchmark regressions are not driven by the presence of observations from any one of these regions.

Finally, instead of having the age dependency ratio as the control as in our benchmark model, we consider the log population as the control as in the benchmark models of Ram (2009), and Jetter and Parmeter (2015), and report the results in Table 13. As well, following Ram (2009) we also add the urbanization rate and the log population density as additional controls. Again, the results with the KOF indexes of globalization are similar to those for the benchmark regressions but not necessarily for the measures of trade openness.

To sum up, our robustness exercises reveal that the KOF indexes of economic and social globalization as well as the overall index are positively associated with inequality and redistribution as is is the case in the benchmark regressions in tables 3 and 4 . As far as the nominal and real trade openness are concerned, they are always positively associated with inequality and redistribution, but their coefficients are not always statistically significant.

\section{Conclusion}

We have theoretically and empirically studied the implications of globalization for inequality and redistribution. Using a comprehensive measure of the extent of redistribution, we find that as economies become more globalized (as measured by the KOF index of globalization) they redistribute more. The results, particularly with respect to 
the KOF index of economic globalization, are robust to the inclusion of a variety of controls and to the exclusion of outliers. An implication is that in the absence of redistributive measures by the government, globalization would have raised the effective inequality even more.

\section{References}

[1] Alcala, F., and Ciccone, A. (2004). Trade and Productivity. Quarterly Journal of Economics, 119 (2), 613646.

[2] Alesina, A., and Wacziarg, R. (1998). Openness, Country Size and Government. Journal of Public Economics, 69 (3), 305-321.

[3] Bergh, A., and Nilsson, T. (2010). Do Liberalization and Globalization Increase Income Inequality?. European Journal of Political Economy, 26 (4), 488-505.

[4] Dabla-Norris, E., Kochhar, K., Suphaphiphat, N., Ricka, F., and Tsounta, E. (2015). Causes and Consequences of Income Inequality: A Global Perspective. International Monetary Fund Staff Discussion Note, No: 15/13, Washington, D.C.: International Monetary Fund.

[5] Dreher, A. (2006a). Does Globalization Affect Growth? Evidence from a New Index of Globalization. Applied Economics, 38 (10), 1091-1110.

[6] Dreher, A. (2006b). The Influence of Globalization on Taxes and Social Policy: An Empirical Analysis for OECD Countries. European Journal of Political Economy, 22 (1), 179-201.

[7] Dreher, A., and Gaston, N. (2008). Has Globalization Increased Inequality?. Review of International Economics, $16(3), 516-536$.

[8] Dreher, A., Gaston, N., and Martens, P. (2008). Measuring Globalisation - Gauging its Consequences. New York City, NY: Springer.

[9] Feenstra, R.C., Inklaar, R., and Timmer, M. P. (2015). The Next Generation of the Penn World Table. American Economic Review, forthcoming.

[10] Goldberg, P.K., and Pavcnik, N. (2007). Distributional Effects of Globalization in Developing Countries. Journal of Economic Literature, 45 (1), 39-82.

[11] Jetter, M., and Parmeter, C.F. (2015). Trade Openness and Bigger Governments: The Role of Country Size Revisited. European Journal of Political Economy, 37, 49-63. 
[12] Kaiser, B. (2014). RHAUSMAN: Stata module to perform Robust Hausman Specification Test. Statistical Software Components S457909, Boston College Department of Economics.

[13] Meinhard, S., and Portrafke, N. (2012). The Globalization-Welfare State Nexus Reconsidered. Review of International Economics, 20 (2), 271-287.

[14] Morgan, J., and Kelly, N.J. (2013). Market Inequality and Redistribution in Latin America and the Caribbean. Journal of Politics, 75 (3), 672-685.

[15] Ostry, J.D., Berg, A., and Tsangarides, C.G. (2014). Redistribution, Inequality, and Growth. International Monetary Fund Staff Discussion Notes, No: 14/02, Washington, D.C.: International Monetary Fund.

[16] Potrafke, N. (2015). The Evidence on Globalisation. World Economy, 38 (3), 509-552.

[17] Ram, R. (2009). Openness, Country Size, and Government Size: Additional Evidence from a Large Crosscountry Panel. Journal of Public Economics, 93 (1-2), 213-218.

[18] Rodrik, D. (1998). Why Do More Open Economies Have Bigger Governments?. Journal of Political Economy, $106(5), 997-1032$.

[19] Schulze, G.G., and Ursprung, H.W. (1999). Globalisation of the Economy and the Nation State. World Economy, 22 (3), 295-352.

[20] Solt, F. (2009). Standardizing the World Income Inequality Database. Social Science Quarterly, 90 (2), 231-242.

[21] Solt, F. (2014). The Standardized World Income Inequality Database. Working Paper, University of Iowa, mimeo. 


\section{Theoretical Appendix}

\subsection{Proof of Result 1}

Eliminate $M$ from (9) and (11) using (10) to obtain

$$
\begin{aligned}
& \gamma A\left(1+\left(\frac{\phi}{w}\right)^{1-\sigma}\right)^{\frac{\sigma \gamma}{\sigma-1}-1} L^{\gamma-1} H^{1-\gamma}=w \\
& (1-\gamma) A\left(1+\left(\frac{\phi}{w}\right)^{1-\sigma}\right)^{\frac{\sigma \gamma}{\sigma-1}} L^{\gamma} H^{-\gamma}=r
\end{aligned}
$$

Therefore,

$$
\frac{r}{w}=\frac{(1-\gamma)\left(1+\left(\frac{\phi}{w}\right)^{1-\sigma}\right) L}{\gamma H}
$$

It follows from above that

$$
\frac{w}{r} \frac{d\left(\frac{r}{w}\right)}{d \phi}=\frac{(\sigma-1)}{\phi} \Omega\left(\frac{\phi}{w}\left(\frac{d w}{d \phi}\right)-1\right)
$$

where we use the compact notation: $\Omega \equiv \frac{\left(\frac{\phi}{w}\right)^{1-\sigma}}{1+\left(\frac{\phi}{w}\right)^{1-\sigma}}$. Clearly, $0<\Omega<1$.

Next, we obtain the following expression for $\frac{d w}{d \phi}$ from (20) after doing a little bit of algebra.

$$
\frac{\phi}{w} \frac{d w}{d \phi}=\frac{(\sigma \gamma-\sigma+1) \Omega}{-1+(\sigma \gamma-\sigma+1) \Omega}
$$

Therefore,

$$
\frac{w}{r} \frac{d\left(\frac{r}{w}\right)}{d \phi}=\frac{(\sigma-1)}{\phi} \Omega\left(\frac{(\sigma \gamma-\sigma+1) \Omega}{-1+(\sigma \gamma-\sigma+1) \Omega}-1\right)
$$

Re-write the above as

$$
\frac{w}{r} \frac{d\left(\frac{r}{w}\right)}{d \phi}=\frac{(\sigma-1)}{\phi} \Omega\left(\frac{1}{-1+(\sigma \gamma-\sigma+1) \Omega}\right)
$$

Verify that $-1+(\sigma \gamma-\sigma+1) \Omega<0$. If $\sigma \gamma-\sigma+1<0$, then it is obviously true. If $\sigma \gamma-\sigma+1>0$ then $\sigma \gamma-\sigma+1<1$, therefore, $-1+(\sigma \gamma-\sigma+1) \Omega<0$ (recall that $0<\Omega<1$ ). Therefore, the sign of $\frac{d\left(\frac{r}{w}\right)}{d \phi}$ is the opposite of the sign of $(\sigma-1)$ which is result 1 . 
Figure 1: Globalization, Inequality, and Redistribution
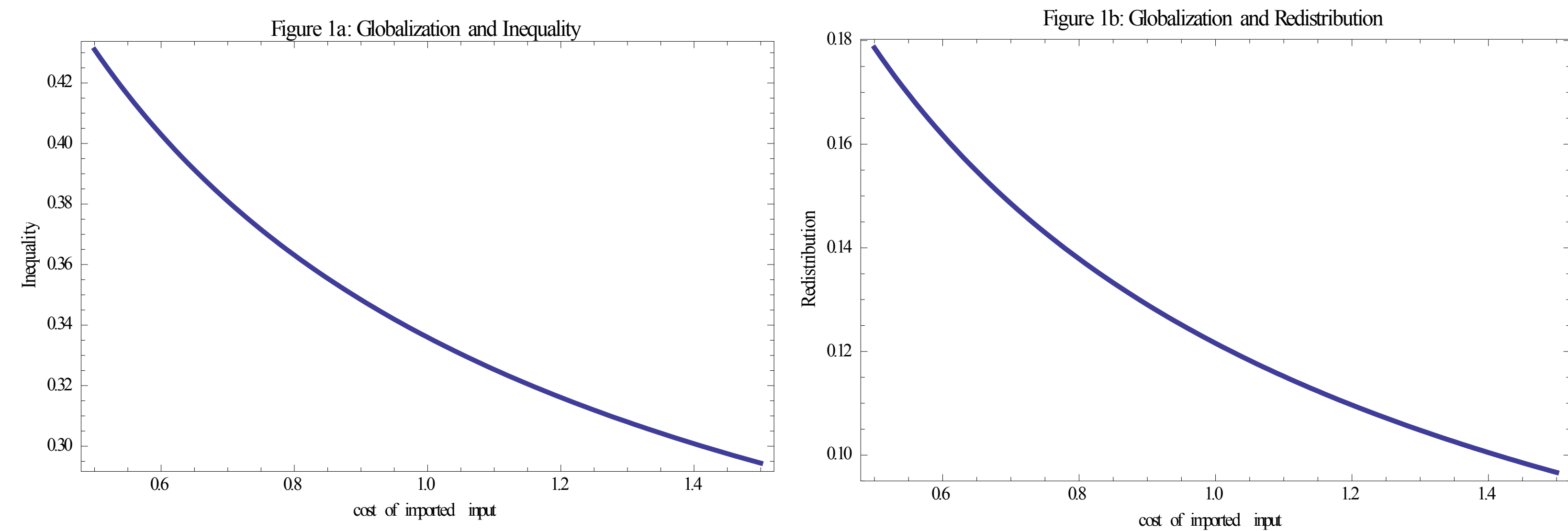
Table 1

Descriptive Summary Statistics

\begin{tabular}{|c|c|c|c|c|c|c|c|}
\hline Variables & Definition & Data Source & Mean & $\begin{array}{l}\text { Standard } \\
\text { Deviation } \\
\end{array}$ & Minimum & Maximum & Observations \\
\hline Gini Index of Market Income & Level of Index & SWIID 5.0: Solt (2014) & 44.56 & 8.002 & 18.88 & 70.30 & 933 \\
\hline Redistribution & Level of Index & SWIID 5.0: Solt (2014) & 6.551 & 6.492 & -14.73 & 26.43 & 933 \\
\hline Economic Globalization & Level of Index & KOF: Dreher (2006a) & 52.58 & 18.65 & 10.06 & 97.40 & 884 \\
\hline Social Globalization & Level of Index & KOF: Dreher (2006a) & 43.95 & 21.93 & 6.674 & 92.97 & 884 \\
\hline Political Globalization & Level of Index & KOF: Dreher (2006a) & 63.01 & 21.36 & 7.572 & 97.78 & 884 \\
\hline Overall Globalization & Level of Index & KOF: Dreher (2006a) & 52.05 & 17.76 & 13.17 & 91.75 & 884 \\
\hline Real Trade Openness (Real Merchandise Exports plus Real Imports Relative to PPP GDP) & Level, Ratio & PWT 8.1: Feenstra et al. (2015) & 54.15 & 80.57 & 1.439 & 1600 & 859 \\
\hline Nominal Trade Openness (Merchandise Exports plus Imports Relative to Nominal GDP) & Level, Ratio & PWT 8.1: Feenstra et al. (2015) & 75.16 & 48.54 & 6.487 & 414.4 & 859 \\
\hline Government Size (Share of Government Consumption in GDP) & Level, Ratio & PWT 8.1: Feenstra et al. (2015) & 20.17 & 10.15 & 2.419 & 126.3 & 890 \\
\hline Population, Total & Logarithmic form & PWT 8.1: Feenstra et al. (2015) & 2.393 & 1.661 & -2.669 & 7.181 & 890 \\
\hline Per Capita GDP (PPPs, Constant 2005US\$) & Logarithmic form & PWT 8.1: Feenstra et al. (2015) & 8.631 & 1.145 & 5.497 & 11.09 & 890 \\
\hline Age Dependency Ratio (\% of Working-age Population) & Level of Index & World Bank, World Development Indicators & 67.25 & 18.91 & 35.86 & 119.9 & 929 \\
\hline Urban Population (\% of Total) & Level, Ratio & World Bank, World Development Indicators & 54.26 & 22.86 & 5.127 & 100.0 & 933 \\
\hline Population Density (People per Square Km of Land Area) & Logarithmic form & World Bank, World Development Indicators & 4.075 & 1.378 & 0.362 & 8.899 & 921 \\
\hline Diversification of Exports Index & Level of Index & International Monetary Fund & 3.053 & 1.183 & 1.040 & 6.296 & 883 \\
\hline Inflation, Consumer Prices (Annual \%) & Percentage & World Bank, World Development Indicators & 31.13 & 186.7 & -11.44 & 3330 & 819 \\
\hline Index of Human Capital per Person & Level of Index & PWT 8.1: Feenstra et al. (2015) & 2.355 & 0.583 & 1.113 & 3.612 & 797 \\
\hline Institutional Quality (Executive Constraints Concept) & Index from 1 to 7 & Polity IV Annual Time Series & 5.002 & 2.049 & 1.000 & 7.000 & 875 \\
\hline Civil Liberties Ratings ( 1 Representing the Most Free; 7 the Least Free) & Index from 1 to 7 & Freedom House, Freedom in the World Database & 3.316 & 1.728 & 1.000 & 7.000 & 905 \\
\hline Level of Institutionalized Democracy & Index from 0 to 10 & Polity IV Annual Time Series & 5.703 & 3.932 & 0.000 & 10.00 & 875 \\
\hline
\end{tabular}


Table 2

Correlation Matrix (Five-year Averaged Data)

\begin{tabular}{|c|c|c|c|c|c|c|c|c|c|c|c|}
\hline Regressors & $\begin{array}{c}\text { Market } \\
\text { Gini }\end{array}$ & Redistribution & $\begin{array}{c}\text { Economic } \\
\text { Globalization }\end{array}$ & $\begin{array}{c}\text { Social } \\
\text { Globalization }\end{array}$ & $\begin{array}{c}\text { Political } \\
\text { Globalization }\end{array}$ & $\begin{array}{c}\text { Overall } \\
\text { Globalization } \\
\end{array}$ & $\begin{array}{c}\text { Real Trade } \\
\text { Openness }\end{array}$ & $\begin{array}{c}\text { Nominal Trade } \\
\text { Openness }\end{array}$ & $\begin{array}{c}\text { Government } \\
\text { Size }\end{array}$ & $\begin{array}{c}\text { Per Capita } \\
\text { GDP }\end{array}$ & $\begin{array}{c}\text { Age Dependency } \\
\text { Ratio }\end{array}$ \\
\hline Market Gini & 1.000 & - & - & - & - & - & - & - & - & - & - \\
\hline Redistribution & 0.131 & 1.000 & - & - & - & - & - & - & - & - & - \\
\hline Economic Globalization & 0.120 & 0.577 & 1.000 & - & - & - & - & - & - & - & - \\
\hline Social Globalization & 0.010 & 0.702 & 0.815 & 1.000 & - & - & - & - & - & - & - \\
\hline Political Globalization & 0.039 & 0.485 & 0.396 & 0.538 & 1.000 & - & - & - & - & - & - \\
\hline Overall Globalization & 0.062 & 0.698 & 0.883 & 0.944 & 0.716 & 1.000 & - & - & - & - & - \\
\hline Real Trade Openness & 0.036 & 0.205 & 0.415 & 0.356 & 0.126 & 0.363 & 1.000 & - & - & - & - \\
\hline Nominal Trade Openness & -0.012 & 0.111 & 0.594 & 0.384 & -0.117 & 0.369 & 0.423 & 1.000 & - & - & - \\
\hline Government Size & -0.128 & -0.054 & -0.019 & -0.054 & -0.248 & -0.109 & 0.369 & 0.129 & 1.000 & - & - \\
\hline Per Capita GDP & -0.014 & 0.669 & 0.699 & 0.850 & 0.479 & 0.812 & 0.141 & 0.267 & -0.144 & 1.000 & - \\
\hline Age Dependency Ratio & 0.215 & -0.501 & -0.580 & -0.724 & -0.421 & -0.690 & -0.196 & -0.272 & 0.061 & -0.770 & 1.000 \\
\hline
\end{tabular}


Table 3

Benchmark Regression: Dependent Variable Market Gini (Five-year Averaged Data)

\begin{tabular}{|c|c|c|c|c|c|c|}
\hline Regressors & $\mathrm{FE}(1)$ & FE (2) & FE (3) & FE (4) & FE (5) & FE (6) \\
\hline Constant Term & $12.89(9.133)$ & $10.49(9.433)$ & $14.09(8.276)^{*}$ & $23.52(7.961)^{* * *}$ & $10.41(9.136)$ & $16.86(8.268)^{* *}$ \\
\hline Per Capita GDP & $2.736(0.976)^{* * *}$ & $3.307(0.937)^{* * *}$ & $1.196(0.906)$ & $0.412(0.850)$ & $2.628(0.955)^{* * *}$ & $0.602(0.922)$ \\
\hline Age Dependency Ratio & $0.089(0.033)^{* *}$ & $0.081(0.035)^{* * *}$ & $0.155(0.033)^{* * *}$ & $0.145(0.034)^{* * *}$ & $0.117(0.035)^{* * *}$ & $0.176(0.033)^{* * *}$ \\
\hline Nominal Trade Openness & $0.029(0.012)^{* *}$ & - & - & - & - & - \\
\hline Real Trade Openness & - & $0.0039(0.004)$ & - & - & - & - \\
\hline Economic Globalization & - & - & $0.188(0.030)^{* * *}$ & - & - & - \\
\hline Social Globalization & - & - & - & $0.178(0.032)^{* * *}$ & - & - \\
\hline Political Globalization & - & - & - & - & $0.058(0.025)^{* *}$ & - \\
\hline Overall Globalization & - & - & - & - & - & $0.206(0.035)^{* * *}$ \\
\hline Observations & 859 & 859 & 859 & 859 & 859 & 859 \\
\hline Number of Countries & 140 & 140 & 140 & 140 & 140 & 140 \\
\hline Cluster-robust Hausman & $10.8[0.013]$ & $9.68[0.021]$ & $6.47[0.090]$ & $12.9[0.005]$ & $8.07[0.044]$ & $7.80[0.050]$ \\
\hline R-Squared (Within) & 0.067 & 0.059 & 0.163 & 0.148 & 0.074 & 0.155 \\
\hline
\end{tabular}

Notes: The dependent variable is the Gini index of market income. The Cluster-robust Hausman test shows whether the results of the fixed effects or the random effects estimations are valid (null hypothesis: the difference in coefficients is not systematic, i.e., fixed effects estimations are consistent). See Kaiser (2014) for details. We report the robust standard errors clustered at the country level. The standard errors are in parentheses and the p-values are in brackets. ***, ** and * indicate statistical significance at the $1 \%, 5 \%$, and $10 \%$ levels, respectively. 
Table 4

Benchmark Regression: Dependent Variable Redistribution (Five-year Averaged Data)

\begin{tabular}{|c|c|c|c|c|c|c|}
\hline Regressors & FE (1) & FE (2) & FE (3) & FE (4) & FE (5) & FE (6) \\
\hline Constant Term & $-10.52(4.108)^{* * *}$ & $-11.99(4.342)^{* * *}$ & $-10.18(3.787)^{* * *}$ & $-6.735(3.515)^{*}$ & $-11.34(4.311)^{* * *}$ & $-9.406(3.838)^{* *}$ \\
\hline Per Capita GDP & $1.633(0.434)^{* * *}$ & $1.914(0.452)^{* * *}$ & $1.082(0.393)^{* * *}$ & $0.825(0.371)^{* *}$ & $1.816(0.452)^{* * *}$ & $0.994(0.402)^{* *}$ \\
\hline Age Dependency Ratio & $0.034(0.011)^{* * *}$ & $0.031(0.011)^{* * *}$ & $0.056(0.012)^{* * *}$ & $0.051(0.013)^{* * *}$ & $0.030(0.014)^{* * *}$ & $0.059(0.014)^{* * *}$ \\
\hline Nominal Trade Openness & $0.013(0.005)^{* *}$ & - & - & - & - & - \\
\hline Real Trade Openness & - & $0.0033(0.0016)^{* *}$ & - & - & - & - \\
\hline Economic Globalization & - & - & $0.073(0.017)^{* * *}$ & - & - & - \\
\hline Social Globalization & - & - & - & $0.066(0.018)^{* * *}$ & - & - \\
\hline Political Globalization & - & - & - & - & $0.006(0.010)$ & - \\
\hline Overall Globalization & - & - & - & - & - & $0.069(0.019)^{* * *}$ \\
\hline Observations & 859 & 859 & 859 & 859 & 859 & 859 \\
\hline Number of Countries & 140 & 140 & 140 & 140 & 140 & 140 \\
\hline Cluster-robust Hausman & $21.2[0.000]$ & $16.4[0.001]$ & $19.5[0.000]$ & $22.4[0.000]$ & $25.3[0.000]$ & $22 . .7[0.000]$ \\
\hline R-Squared (Within) & 0.093 & 0.090 & 0.149 & 0.136 & 0.084 & 0.129 \\
\hline
\end{tabular}

Notes: The dependent variable is the redistribution. The Cluster-robust Hausman test shows whether the results of the fixed effects or the random effects estimations are valid (null hypothesis: the difference in coefficients is not systematic, i.e., fixed effects estimations are consistent). See Kaiser (2014) for details. We report the robust standard errors clustered at the country level. The standard errors are in parentheses and the p-values are in brackets. ${ }^{* * *},{ }^{* *}$ and ${ }^{*}$ indicate statistical significance at the $1 \%, 5 \%$, and $10 \%$ levels, respectively. 
Table 5

Government Size and Globalization (Five-year Averaged Data)

\begin{tabular}{|c|c|c|c|c|c|c|}
\hline Regressors & $\begin{array}{c}\text { Government } \\
\text { Size (PWT 8.1) }\end{array}$ & $\begin{array}{l}\text { Government } \\
\text { Size (PWT 8.1) }\end{array}$ & $\begin{array}{c}\text { Government } \\
\text { Size (PWT 8.1) }\end{array}$ & $\begin{array}{c}\text { Government } \\
\text { Size (PWT 8.1) }\end{array}$ & $\begin{array}{c}\text { Government } \\
\text { Size (PWT 8.1) }\end{array}$ & $\begin{array}{c}\text { Government } \\
\text { Size (PWT 8.1) }\end{array}$ \\
\hline Constant Term & $35.55(27.28)$ & $18.18(17.11)$ & $32.53(27.65)$ & $33.35(29.81)$ & $35.57(26.10)$ & $30.41(28.60)$ \\
\hline Per Capita GDP & $-2.989(2.655)$ & $-1.558(1.604)$ & $-1.658(3.087)$ & $-2.190(3.165)$ & $-0.565(2.743)$ & $-0.804(3.336)$ \\
\hline Age Dependency Ratio & $0.097(0.100)$ & $0.173(0.069)^{* *}$ & $0.056(0.084)$ & $0.076(0.089)$ & $-0.029(0.083)$ & $0.024(0.078)$ \\
\hline Nominal Trade Openness & $0.045(0.027)$ & - & - & - & - & - \\
\hline Real Trade Openness & - & $0.062(0.006)^{* * *}$ & - & - & - & - \\
\hline Economic Globalization & - & - & $-0.044(0.076)$ & - & - & - \\
\hline Social Globalization & - & - & - & $0.002(0.061)$ & - & - \\
\hline Political Globalization & - & - & - & - & $-0.143(0.055)^{* *}$ & - \\
\hline Overall Globalization & - & - & - & - & - & $-0.104(0.091)$ \\
\hline Observations & 859 & 859 & 859 & 859 & 859 & 859 \\
\hline Number of Countries & 140 & 140 & 140 & 140 & 140 & 140 \\
\hline R-Squared (Within) & 0.042 & 0.247 & 0.034 & 0.033 & 0.070 & 0.041 \\
\hline
\end{tabular}

Notes: The robust standard errors those are clustered at the country levels are in parentheses. ${ }^{* *}$ and ${ }^{* *}$ indicate statistical significance at the $1 \%$ and $5 \%$ levels, respectively. 
Table 6a

Benchmark Regressions: Low- and Lower Middle Income Economies

\begin{tabular}{|c|c|c|c|c|c|c|c|c|c|c|c|c|}
\hline Regressors & Market Gini & Market Gini & Market Gini & Market Gini & Market Gini & Market Gini & Redistribution & Redistribution & Redistribution & Redistribution & Redistribution & Redistribution \\
\hline Nominal Trade Openness & $0.005(0.021)$ & - & - & - & - & - & $0.001(0.005)$ & - & - & - & - & - \\
\hline Real Trade Openness & - & $-0.003(0.002)$ & - & - & - & - & - & $0.0012(0.005)$ & - & - & - & - \\
\hline Economic Globalization & - & - & $0.134(0.054)^{* *}$ & - & - & - & - & - & $0.016(0.023)$ & - & - & - \\
\hline Social Globalization & - & - & - & $0.103(0.080)$ & - & - & - & - & - & $0.013(0.031)$ & - & - \\
\hline Political Globalization & - & - & - & - & $0.010(0.041)$ & - & - & - & - & - & $0.001(0.012)$ & - \\
\hline Overall Globalization & - & - & - & - & - & $0.099(0.069)$ & - & - & - & - & - & $0.012(0.026)$ \\
\hline Observations & 286 & 286 & 286 & 286 & 286 & 286 & 286 & 286 & 286 & 286 & 286 & 286 \\
\hline Number of Countries & 56 & 56 & 56 & 56 & 56 & 56 & 56 & 56 & 56 & 56 & 56 & 56 \\
\hline R-Squared (Within) & 0.011 & 0.015 & 0.048 & 0.020 & 0.011 & 0.025 & 0.001 & 0.001 & 0.006 & 0.002 & 0.001 & 0.003 \\
\hline
\end{tabular}

Notes: The constant term, the per capita GDP and the age dependency ratio are also estimated, but their coefficients are not reported. The robust standard errors those are clustered at the country levels are in parentheses. ${ }^{* *}$ indicate statistical significance at the $5 \%$ level.

Table $6 \mathrm{~b}$

Benchmark Regressions: Upper Middle- and High Income Economies

\begin{tabular}{|c|c|c|c|c|c|c|c|c|c|c|c|c|}
\hline Regressors & Market Gini & Market Gini & Market Gini & Market Gini & Market Gini & Market Gini & Redistribution & Redistribution & Redistribution & Redistribution & Redistribution & Redistribution \\
\hline Nominal Trade Openness & $0.026(0.014)^{*}$ & - & - & - & - & - & $0.013(0.007)^{*}$ & - & - & - & - & - \\
\hline Real Trade Openness & - & $0.026(0.010)^{* *}$ & - & - & - & - & - & $0.014(0.006)^{* *}$ & - & - & - & - \\
\hline Economic Globalization & - & - & $0.187(0.034)^{* * *}$ & - & - & - & - & - & $0.084(0.020)^{* * * *}$ & - & - & - \\
\hline Social Globalization & - & - & - & $0.164(0.034)^{* * *}$ & - & - & - & - & - & $0.061(0.020)^{* * *}$ & - & - \\
\hline Political Globalization & - & - & - & - & $0.076(0.029)^{* *}$ & - & - & - & - & - & $0.004(0.014)$ & - \\
\hline Overall Globalization & - & - & - & - & - & $0.217(0.037)^{* * * *}$ & - & - & - & - & - & $0.075(0.023)^{* * *}$ \\
\hline Observations & 573 & 573 & 573 & 573 & 573 & 573 & 573 & 573 & 573 & 573 & 573 & 573 \\
\hline Number of Countries & 84 & 84 & 84 & 84 & 84 & 84 & 84 & 84 & 84 & 84 & 84 & 84 \\
\hline R-Squared (Within) & 0.159 & 0.168 & 0.267 & 0.250 & 0.178 & 0.270 & 0.147 & 0.156 & 0.213 & 0.183 & 0.139 & 0.184 \\
\hline
\end{tabular}

Notes: The constant term, the per capita GDP and the age dependency ratio are also estimated, but their coefficients are not reported. The robust standard errors those are clustered at the country levels are in parentheses. ${ }^{* * *},{ }^{* *}$ and ${ }^{*}$ indicate statistical significance at the $1 \%, 5 \%$, and $10 \%$ levels, respectively. 
Table 7

Benchmark Regression: Dependent Variable Market Gini (Balanced Panel and Five-year Averaged Data)

\begin{tabular}{|c|c|c|c|c|c|c|}
\hline Regressors & FE (1) & FE (2) & FE (3) & FE (4) & FE (5) & FE (6) \\
\hline Constant Term & $-7.976(15.41)$ & $-5.529(13.38)$ & $6.938(12.08)$ & $16.06(12.37)$ & $-7.447(12.60)$ & $13.59(11.74)$ \\
\hline Per Capita GDP & $5.171(1.738)^{* * *}$ & $4.783(1.416)^{* * *}$ & $1.918(1.414)$ & $1.296(1.502)$ & $4.288(1.325)^{* * *}$ & $0.564(1.450)$ \\
\hline Age Dependency Ratio & $0.063(0.037)^{*}$ & $0.067(0.039)^{*}$ & $0.116(0.038)^{* * *}$ & $0.110(0.041)^{* *}$ & $0.106(0.036)^{* * *}$ & $0.155(0.038)^{* * *}$ \\
\hline Nominal Trade Openness & $0.005(0.021)$ & - & - & - & - & - \\
\hline Real Trade Openness & - & $0.021(0.016)$ & - & - & - & - \\
\hline Economic Globalization & - & - & $0.212(0.046)^{* * *}$ & - & - & - \\
\hline Social Globalization & - & - & - & $0.176(0.052)^{* * *}$ & - & - \\
\hline Political Globalization & - & - & - & - & $0.073(0.040)^{*}$ & - \\
\hline Overall Globalization & - & - & - & - & - & $0.263(0.055)^{* * *}$ \\
\hline Observations & 378 & 378 & 378 & 378 & 378 & 378 \\
\hline Number of Countries & 42 & 42 & 42 & 42 & 42 & 42 \\
\hline R-Squared (Within) & 0.217 & 0.228 & 0.336 & 0.312 & 0.237 & 0.343 \\
\hline
\end{tabular}

Notes: The dependent variable is the Gini index of market income. We report the robust standard errors clustered at the country level. The standard errors are in parentheses and the p-values are in brackets. ${ }^{* * *},{ }^{* *}$ and ${ }^{*}$ indicate statistical significance at the $1 \%, 5 \%$, and $10 \%$ levels, respectively. 
Table 8

Benchmark Regression: Dependent Variable Redistribution (Balanced Panel and Five-year Averaged Data)

\begin{tabular}{|c|c|c|c|c|c|c|}
\hline Regressors & $\mathrm{FE}(1)$ & $\mathrm{FE}(2)$ & $\mathrm{FE}(3)$ & $\mathrm{FE}(4)$ & FE (5) & $\mathrm{FE}(6)$ \\
\hline Constant Term & $-17.56(8.040)^{* *}$ & $-17.08(7.313)^{* *}$ & $-9.766(6.925)$ & $-6.150(6.762)$ & $-19.44(7.547)^{* * *}$ & $-8.850(7.274)$ \\
\hline Per Capita GDP & $2.573(0.858)^{* * *}$ & $2.505(0.741)^{* * *}$ & $0.807(0.802)$ & $0.738(0.792)$ & $2.970(0.791)^{* * *}$ & $0.647(0.935)$ \\
\hline Age Dependency Ratio & $0.044(0.017)^{* *}$ & $0.044(0.017)^{* *}$ & $0.073(0.017)^{* * *}$ & $0.066(0.018)^{* * *}$ & $0.036(0.023)$ & $0.084(0.022)^{* * *}$ \\
\hline Nominal Trade Openness & $0.010(0.010)$ & - & - & - & - & - \\
\hline Real Trade Openness & - & $0.014(0.009)$ & - & - & - & - \\
\hline Economic Globalization & - & - & $0.128(0.030)^{* * *}$ & - & - & - \\
\hline Social Globalization & - & - & - & $0.093(0.031)^{* * *}$ & - & - \\
\hline Political Globalization & - & - & - & - & $-0.008(0.024)$ & - \\
\hline Overall Globalization & - & - & - & - & - & $0.123(0.042)^{* * *}$ \\
\hline Observations & 378 & 378 & 378 & 378 & 378 & 378 \\
\hline Number of Countries & 42 & 42 & 42 & 42 & 42 & 42 \\
\hline R-Squared (Within) & 0.156 & 0.166 & 0.264 & 0.221 & 0.153 & 0.223 \\
\hline
\end{tabular}

Notes: The dependent variable is the redistribution. We report the robust standard errors clustered at the country level. The standard errors are in parentheses and the $\mathrm{p}$-values are in brackets. ${ }^{* * *}$ and ${ }^{* *}$ indicate statistical significance at the $1 \%$ and $5 \%$ levels, respectively. 
Table 9

Regressions with Annual Data: Dependent Variable Market Gini

\begin{tabular}{|c|c|c|c|c|c|c|}
\hline Regressors & FE (1) & $\mathrm{FE}(2)$ & FE (3) & $\mathrm{FE}(4)$ & FE (5) & FE (6) \\
\hline Constant Term & $8.347(9.715)$ & $8.439(9.747)$ & $13.49(8.649)$ & $19.47(8.018)^{* *}$ & $8.038(9.361)$ & $15.12(8.494)^{*}$ \\
\hline Per Capita GDP & $3.625(0.973)^{* * *}$ & $3.621(0.969)^{* * *}$ & $1.542(0.922)^{*}$ & $0.999(0.820)$ & $3.164(0.973)^{* * *}$ & $1.017(0.933)$ \\
\hline Age Dependency Ratio & $0.071(0.035)^{* *}$ & $0.071(0.035)^{* *}$ & $0.136(0.031)^{* * *}$ & $0.140(0.034)^{* * *}$ & $0.100(0.035)^{* * *}$ & $0.163(0.033)^{* * *}$ \\
\hline Lagged Nominal Trade Openness & $0.0017(0.007)$ & - & - & - & - & - \\
\hline Lagged Real Trade Openness & - & $0.0014(0.001)$ & - & - & - & - \\
\hline Lagged Economic Globalization & - & - & $0.165(0.027)^{* * *}$ & - & - & - \\
\hline Lagged Social Globalization & - & - & - & $0.162(0.031)^{* * *}$ & - & - \\
\hline Lagged Political Globalization & - & - & - & - & $0.039(0.025)$ & - \\
\hline Lagged Overall Globalization & - & - & - & - & - & $0.188(0.036)^{* * *}$ \\
\hline Observations & 3333 & 3333 & 3424 & 3424 & 3424 & 3424 \\
\hline Number of Countries & 137 & 137 & 137 & 137 & 137 & 137 \\
\hline R-Squared (Within) & 0.070 & 0.070 & 0.153 & 0.152 & 0.079 & 0.150 \\
\hline
\end{tabular}

Notes: The dependent variable is the Gini index of market income. We report the robust standard errors clustered at the country level. The standard errors are in parentheses and the $\mathrm{p}$-values are in brackets. ${ }^{* * *},{ }^{* *}$ and ${ }^{*}$ indicate statistical significance at the $1 \%, 5 \%$, and $10 \%$ levels, respectively. 
Table 10

Regressions with Annual Data: Dependent Variable Redistribution

\begin{tabular}{|c|c|c|c|c|c|c|}
\hline Regressors & $\mathrm{FE}(1)$ & $\mathrm{FE}(2)$ & $\mathrm{FE}(3)$ & $\mathrm{FE}(4)$ & FE (5) & FE (6) \\
\hline Constant Term & $-11.53(4.718)^{* * *}$ & $-11.44(4.732)^{* *}$ & $-9.691(4.000)^{* *}$ & $-7.496(3.751)^{* *}$ & $-11.96(4.554)^{* *}$ & $-9.346(4.009)^{* *}$ \\
\hline Per Capita GDP & $1.894(0.493)^{* * *}$ & $1.918(0.498)^{* * *}$ & $1.082(0.434)^{* * *}$ & $0.934(0.387)^{* *}$ & $1.914(0.475)^{* * *}$ & $0.991(0.425)^{* *}$ \\
\hline Age Dependency Ratio & $0.029(0.012)^{* *}$ & $0.028(0.012)^{* *}$ & $0.056(0.012)^{* * *}$ & $0.056(0.013)^{* * *}$ & $0.033(0.015)^{* *}$ & $0.063(0.015)^{* * *}$ \\
\hline Lagged Nominal Trade Openness & $0.0037(0.0026)$ & - & - & - & - & - \\
\hline Lagged Real Trade Openness & - & $0.0005(0.0005)$ & - & - & - & - \\
\hline Lagged Economic Globalization & - & - & $0.071(0.015)^{* * *}$ & - & - & - \\
\hline Lagged Social Globalization & - & - & - & $0.064(0.017)^{* * *}$ & - & - \\
\hline Lagged Political Globalization & - & - & - & - & $0.005(0.011)$ & - \\
\hline Lagged Overall Globalization & - & - & - & - & - & $0.071(0.019)^{* * *}$ \\
\hline Observations & 3333 & 3333 & 3424 & 3424 & 3424 & 3424 \\
\hline Number of Countries & 137 & 137 & 137 & 137 & 137 & 137 \\
\hline R-Squared (Within) & 0.080 & 0.078 & 0.141 & 0.132 & 0.084 & 0.126 \\
\hline
\end{tabular}

Notes: The dependent variable is the redistribution. We report the robust standard errors clustered at the country level. The standard errors are in parentheses and the p-values are in brackets. ${ }^{* * *}$ and ${ }^{* *}$ indicate statistical significance at the $1 \%$ and $5 \%$ levels, respectively. 
Table 11 Sensitivity Analysis: (Including Additional Controls, Five-year Averaged Data)

\begin{tabular}{|c|c|c|c|}
\hline Sensitivity Analysis & Coefficients & Market Gini & Redistribution \\
\hline \multirow{6}{*}{ Results of the Benchmark Regressions } & Nominal Trade Openness & $0.029(0.012)^{* *}$ & $0.013(0.005)^{* *}$ \\
\hline & Real Trade Openness & $0.0039(0.004)$ & $0.0033(0.0016)^{* *}$ \\
\hline & Economic Globalization & $0.188(0.030)^{* * *}$ & $0.073(0.017)^{* * *}$ \\
\hline & Social Globalization & $0.178(0.032)^{* * *}$ & $0.066(0.018)^{* * *}$ \\
\hline & Political Globalization & $0.058(0.025)^{* *}$ & $0.006(0.010)$ \\
\hline & Overall Globalization & $0.206(0.035)^{* * *}$ & $0.069(0.019)^{* * *}$ \\
\hline \multirow{6}{*}{ Including Log Population: Benchmark Model of Meinhard and Portrafke (2012) } & Nominal Trade Openness & $0.030(0.012)^{* *}$ & $0.013(0.005)^{* *}$ \\
\hline & Real Trade Openness & $0.0038(0.004)$ & $0.0034(0.0017)^{* *}$ \\
\hline & Economic Globalization & $0.192(0.032)^{* * *}$ & $0.072(0.016)^{* * *}$ \\
\hline & Social Globalization & $0.180(0.033)^{* * *}$ & $0.066(0.018)^{* * *}$ \\
\hline & Political Globalization & $0.073(0.026)^{* * *}$ & $0.004(0.011)$ \\
\hline & Overall Globalization & $0.220(0.036)^{* * *}$ & $0.069(0.020)^{* * *}$ \\
\hline \multirow{6}{*}{ Including Human Capital Level: Benchmark Model of Bergh and Nilsson (2010) } & Nominal Trade Openness & $0.021(0.012)^{*}$ & $0.010(0.006)^{*}$ \\
\hline & Real Trade Openness & $0.0033(0.003)$ & $0.0020(0.0015)$ \\
\hline & Economic Globalization & $0.204(0.036)^{* * *}$ & $0.070(0.018)^{* * *}$ \\
\hline & Social Globalization & $0.204(0.039)^{* * *}$ & $0.053(0.020)^{* * *}$ \\
\hline & Political Globalization & $0.052(0.026)^{* *}$ & $-0.010(0.011)$ \\
\hline & Overall Globalization & $0.249(0.043)^{* * *}$ & $0.057(0.021)^{* * *}$ \\
\hline \multirow{6}{*}{ Including Urbanization Rate: Benchmark Model of Rodrik (1998) } & Nominal Trade Openness & $0.029(0.011)^{* *}$ & $0.014(0.005)^{* * *}$ \\
\hline & Real Trade Openness & $0.004(0.004)$ & $0.0036(0.0017)^{* *}$ \\
\hline & Economic Globalization & $0.197(0.031)^{* * *}$ & $0.080(0.016)^{* * *}$ \\
\hline & Social Globalization & $0.189(0.033)^{* * *}$ & $0.074(0.018)^{* * *}$ \\
\hline & Political Globalization & $0.060(0.024)^{* *}$ & $0.009(0.010)$ \\
\hline & Overall Globalization & $0.222(0.036)^{* * *}$ & $0.079(0.019)^{* * *}$ \\
\hline \multirow[b]{3}{*}{ Including Civil Liberties (Index) } & Nominal Trade Openness & $0.027(0.011)^{* *}$ & $0.013(0.005)^{* *}$ \\
\hline & Real Trade Openness & $0.003(0.0035)$ & $0.0031(0.0015)^{* *}$ \\
\hline & Economic Globalization & $0.191(0.031)^{* * *}$ & $0.075(0.016)^{* * *}$ \\
\hline
\end{tabular}




\begin{tabular}{|c|c|c|c|}
\hline & Social Globalization & $0.178(0.033)^{* * * *}$ & $0.069(0.018)^{* * *}$ \\
\hline & Political Globalization & $0.054(0.024)^{* *}$ & $-0.001(0.009)$ \\
\hline & Overall Globalization & $0.212(0.036)^{* * *}$ & $0.070(0.018)^{* * *}$ \\
\hline \multirow{6}{*}{ Including Democracy (Index) } & Nominal Trade Openness & $0.025(0.012)^{* *}$ & $0.012(0.005)^{* *}$ \\
\hline & Real Trade Openness & $0.0035(0.003)$ & $0.0031(0.0016)^{*}$ \\
\hline & Economic Globalization & $0.188(0.032)^{* * *}$ & $0.071(0.016)^{* * *}$ \\
\hline & Social Globalization & $0.178(0.033)^{* * * *}$ & $0.063(0.017)^{* * *}$ \\
\hline & Political Globalization & $0.059(0.025)^{* *}$ & $0.004(0.010)$ \\
\hline & Overall Globalization & $0.211(0.036)^{* * *}$ & $0.066(0.018)^{* * *}$ \\
\hline \multirow{6}{*}{ Including Institutional Quality } & Nominal Trade Openness & $0.026(0.012)^{* *}$ & $0.012(0.005)^{* *}$ \\
\hline & Real Trade Openness & $0.0038(0.0035)$ & $0.0033(0.0016)^{* *}$ \\
\hline & Economic Globalization & $0.191(0.031)^{* * *}$ & $0.074(0.016)^{* * *}$ \\
\hline & Social Globalization & $0.180(0.033)^{* * *}$ & $0.066(0.018)^{* * *}$ \\
\hline & Political Globalization & $0.062(0.024)^{* *}$ & $0.006(0.010)$ \\
\hline & Overall Globalization & $0.213(0.035)^{* * * *}$ & $0.070(0.018)^{* * *}$ \\
\hline \multirow{6}{*}{ Including Inflation Rate } & Nominal Trade Openness & $0.027(0.013)^{* *}$ & $0.014(0.006)^{* *}$ \\
\hline & Real Trade Openness & $0.0042(0.0036)$ & $0.0034(0.0015)^{* *}$ \\
\hline & Economic Globalization & $0.185(0.033)^{* * * *}$ & $0.079(0.018)^{* * *}$ \\
\hline & Social Globalization & $0.162(0.035)^{* * *}$ & $0.069(0.020)^{* * *}$ \\
\hline & Political Globalization & $0.041(0.030)$ & $0.009(0.013)$ \\
\hline & Overall Globalization & $0.203(0.043)^{* * * *}$ & $0.082(0.024)^{* * *}$ \\
\hline \multirow{6}{*}{ Including Diversification of Exports } & Nominal Trade Openness & $0.032(0.014)^{* *}$ & $0.014(0.006)^{* *}$ \\
\hline & Real Trade Openness & $0.0041(0.004)$ & $0.0035(0.0017)^{* *}$ \\
\hline & Economic Globalization & $0.197(0.030)^{* * *}$ & $0.077(0.016)^{* * *}$ \\
\hline & Social Globalization & $0.183(0.032)^{* * *}$ & $0.070(0.018)^{* * *}$ \\
\hline & Political Globalization & $0.060(0.026)^{* *}$ & $0.007(0.010)$ \\
\hline & Overall Globalization & $0.216(0.035)^{* * * *}$ & $0.074(0.019)^{* * * *}$ \\
\hline
\end{tabular}

Notes: The constant term, per capita GDP and the age dependency ratio are also estimated, but their coefficients are not reported. The robust standard errors those are clustered at the country levels are in parentheses. ${ }^{* * *},{ }^{* *}$ and ${ }^{*}$ indicate statistical significance at the $1 \%, 5 \%$, and $10 \%$ levels, respectively. 
Table 12

Sensitivity Analysis: (Different Cases, Five-year Averaged Data)

\begin{tabular}{|c|c|c|c|}
\hline Sensitivity Analysis & Coefficients & Market Gini & Redistribution \\
\hline \multirow{6}{*}{ Results of the Benchmark Regressions } & Nominal Trade Openness & $0.029(0.012)^{* *}$ & $0.013(0.005)^{* *}$ \\
\hline & Real Trade Openness & $0.0039(0.004)$ & $0.0033(0.0016)^{* *}$ \\
\hline & Economic Globalization & $0.188(0.030)^{* * *}$ & $0.073(0.017)^{* * *}$ \\
\hline & Social Globalization & $0.178(0.032)^{* * *}$ & $0.066(0.018)^{* * *}$ \\
\hline & Political Globalization & $0.058(0.025)^{* *}$ & $0.006(0.010)$ \\
\hline & Overall Globalization & $0.206(0.035)^{* * *}$ & $0.069(0.019)^{* * *}$ \\
\hline \multirow{6}{*}{ Excluding Extreme Units of Inequality and Redistribution Measures } & Nominal Trade Openness & $0.027(0.011)^{* *}$ & $0.0076(0.0038)^{* *}$ \\
\hline & Real Trade Openness & $0.0031(0.0033)$ & $0.0024(0.0012)^{* *}$ \\
\hline & Economic Globalization & $0.181(0.030)^{* * *}$ & $0.048(0.017)^{* * *}$ \\
\hline & Social Globalization & $0.173(0.033)^{* * *}$ & $0.051(0.018)^{* * *}$ \\
\hline & Political Globalization & $0.069(0.023)^{* * *}$ & $-0.003(0.008)$ \\
\hline & Overall Globalization & $0.209(0.035)^{* * *}$ & $0.043(0.018)^{* *}$ \\
\hline \multirow{6}{*}{ Excluding Extreme Units of Globalization Measures } & Nominal Trade Openness & $0.039(0.014)^{* * *}$ & $0.015(0.006)^{* *}$ \\
\hline & Real Trade Openness & $0.041(0.010)^{* * *}$ & $0.021(0.005)^{* * *}$ \\
\hline & Economic Globalization & $0.194(0.030)^{* * *}$ & $0.082(0.016)^{* * *}$ \\
\hline & Social Globalization & $0.181(0.032)^{* * *}$ & $0.067(0.018)^{* * *}$ \\
\hline & Political Globalization & $0.040(0.028)$ & $0.005(0.011)$ \\
\hline & Overall Globalization & $0.210(0.036)^{* * *}$ & $0.072(0.019)^{* * *}$ \\
\hline \multirow{6}{*}{ Excluding Sub-Saharan Africa Countries } & Nominal Trade Openness & $0.032(0.013)^{* *}$ & $0.015(0.006)^{* *}$ \\
\hline & Real Trade Openness & $0.0041(0.0035)$ & $0.0035(0.0016)^{* *}$ \\
\hline & Economic Globalization & $0.198(0.030)^{* * *}$ & $0.089(0.018)^{* * *}$ \\
\hline & Social Globalization & $0.186(0.033)^{* * *}$ & $0.070(0.019)^{* * *}$ \\
\hline & Political Globalization & $0.095(0.025)^{* * *}$ & $0.010(0.012)$ \\
\hline & Overall Globalization & $0.237(0.034)^{* * *}$ & $0.082(0.021)^{* * *}$ \\
\hline
\end{tabular}




\begin{tabular}{cccc}
\hline & Nominal Trade Openness & $0.031(0.013)^{* *}$ & $0.014(0.006)^{* *}$ \\
Excluding Latin American and Caribbean Countries & Real Trade Openness & $0.032(0.011)^{* * * *}$ & $0.015(0.006)^{* * *}$ \\
& Economic Globalization & $0.197(0.033)^{* * *}$ & $0.072(0.017)^{* * *}$ \\
& Social Globalization & $0.173(0.034)^{* * *}$ & $0.065(0.019)^{* * *}$ \\
& Political Globalization & $0.058(0.027)^{* *}$ & $0.006(0.011)$ \\
& Overall Globalization & $0.212(0.038)^{* * *}$ & $0.068(0.020)^{* * *}$ \\
\hline Excluding Developing East Asian Countries & Nominal Trade Openness & $0.035(0.012)^{* * *}$ & $0.017(0.006)^{* * *}$ \\
& Real Trade Openness & $0.0041(0.004)$ & $0.0033(0.0017)^{*}$ \\
& Economic Globalization & $0.197(0.031)^{* * *}$ & $0.073(0.017)^{* * *}$ \\
& Social Globalization & $0.183(0.033)^{* * *}$ & $0.070(0.019)^{* * *}$ \\
& Political Globalization & $0.057(0.025)^{* *}$ & $0.007(0.010)$ \\
& Overall Globalization & $0.211(0.036)^{* * *}$ & $0.071(0.019)^{* * *}$ \\
\hline
\end{tabular}

Notes: The constant term, per capita GDP and the age dependency ratio are also estimated, but their coefficients are not reported. The robust standard errors those are clustered at the country levels are in parentheses. ${ }^{* * *}$ and ${ }^{* *}$ indicate statistical significance at the $1 \%$ and $5 \%$ levels, respectively. 
Table 13

Comparison with Ram (2009) and Jetter and Parmeter (2015)

\begin{tabular}{|c|c|c|c|}
\hline Models & Coefficients & Market Gini & Redistribution \\
\hline \multirow{6}{*}{$\begin{array}{l}\text { Benchmark Regression of Ram (2009) and Jetter and Parmeter (2015): } \\
\text { (Per Capita GDP plus Log Population) }\end{array}$} & Nominal Trade Openness & $0.025(0.012)^{*}$ & $0.011(0.005)^{*}$ \\
\hline & Real Trade Openness & $0.0022(0.0034)$ & $0.0025(0.0015)^{*}$ \\
\hline & Economic Globalization & $0.162(0.036)^{* * *}$ & $0.059(0.017)^{* * *}$ \\
\hline & Social Globalization & $0.150(0.033)^{* * *}$ & $0.052(0.018)^{* * *}$ \\
\hline & Political Globalization & $0.057(0.025)^{* *}$ & $-0.002(0.011)$ \\
\hline & Overall Globalization & $0.176(0.040)^{* * *}$ & $0.051(0.019)^{* * *}$ \\
\hline \multirow{6}{*}{ Including Urbanization Rate } & Nominal Trade Openness & $0.026(0.011)^{* *}$ & $0.012(0.005)^{* *}$ \\
\hline & Real Trade Openness & $0.0027(0.0036)$ & $0.0034(0.0016)^{* *}$ \\
\hline & Economic Globalization & $0.180(0.031)^{* * *}$ & $0.073(0.016)^{* * *}$ \\
\hline & Social Globalization & $0.172(0.031)^{* * *}$ & $0.068(0.018)^{* * *}$ \\
\hline & Political Globalization & $0.061(0.024)^{* *}$ & $0.002(0.011)$ \\
\hline & Overall Globalization & $0.201(0.035)^{* * *}$ & $0.068(0.019)^{* * *}$ \\
\hline \multirow{6}{*}{ Including (Urbanization Rate plus Log Population Density) } & Nominal Trade Openness & $0.027(0.012)^{* *}$ & $0.014(0.006)^{* *}$ \\
\hline & Real Trade Openness & $0.0025(0.0037)$ & $0.0038(0.0018)^{* *}$ \\
\hline & Economic Globalization & $0.195(0.031)^{* * *}$ & $0.075(0.016)^{* * *}$ \\
\hline & Social Globalization & $0.188(0.032)^{* * *}$ & $0.075(0.018)^{* * *}$ \\
\hline & Political Globalization & $0.064(0.024)^{* * *}$ & $0.001(0.011)$ \\
\hline & Overall Globalization & $0.216(0.035)^{* * *}$ & $0.071(0.019)^{* * *}$ \\
\hline
\end{tabular}

Notes: The constant term, per capita GDP and the log population are also estimated, but their coefficients are not reported. The robust standard errors those are clustered at the country levels are in parentheses. ${ }^{* * *},{ }^{* *}$ and ${ }^{*}$ indicate statistical significance at the $1 \%, 5 \%$, and $10 \%$ levels, respectively. 
Data Appendix I

Details of the KOF Index of

\begin{tabular}{cc}
\hline Globalization Indices and Variables & Weights \\
\hline Economic Globalization & {$[36 \%]$} \\
\hline i) Actual Flows & $50.00 \%$ \\
\hline Trade (percent of GDP) & $21.77 \%$ \\
Foreign Direct Investment, Stocks (percent of GDP) & $26.62 \%$ \\
Portfolio Investment (percent of GDP) & $24.31 \%$ \\
Income Payments to Foreign Nationals (percent of GDP) & $27.30 \%$ \\
\hline ii) Restrictions & $50.00 \%$ \\
\hline Hidden Import Barriers & $23.59 \%$ \\
Mean Tariff Rate & $27.80 \%$ \\
\hline Taxes on International Trade (percent of current revenue) & $25.90 \%$ \\
Capital Account Restrictions & $22.71 \%$ \\
\hline Social Globalization & {$[38 \%]$} \\
\hline i) Data on Personal Contact & $33.03 \%$ \\
\hline Telephone Traffic & $25.13 \%$ \\
Transfers (percent of GDP) & $2.99 \%$ \\
International Tourism & $26.25 \%$ \\
\hline Foreign Population (percent of total population) & $20.95 \%$ \\
International Letters (per capita) & $24.69 \%$ \\
\hline ii) Data on Information Flows & $35.25 \%$ \\
\hline Internet Users (per 1000 people) & $36.05 \%$ \\
Television (per 1000 people) & $37.63 \%$ \\
Trade in Newspapers (percent of GDP) & $26.32 \%$ \\
\hline iii) Data on Cultural Proximity & $31.72 \%$ \\
\hline Number of McDonald's Restaurants (per capita) & $44.28 \%$ \\
Number of IKEA (per capita) & $44.49 \%$ \\
Trade in books (percent of GDP) & $11.23 \%$ \\
\hline Political Globalization & {$[26 \%]$} \\
\hline Embassies in Country & $24.93 \%$ \\
Membership in International Organizations & $27.21 \%$ \\
Participation in U.N. Security Council Missions & $22.32 \%$ \\
International Treaties & $25.55 \%$ \\
\hline
\end{tabular}

Globalization Data Set 
Data Appendix II

List of Countries in the Panel Data Set (Country and Lending Groups Classification of the World Bank in 2015)

Low-income group in our sample consists of countries with GNI per capita of less than $\$ 4,125$ in 2015. (This group is comprised of countries deemed to be low income with GNI of $\$ 1,045$ or less and lower middle income with GNI between $\$ 1,046$ and $\$ 4,125$ in 2015 , according to the World Bank Classification.) High income group consists of countries with GNI per capita of $\$ 12,736$ or more. (This group is comprised of countries deemed to be upper-middle income with GNI per capita between $\$ 4,125$ and $\$ 12,736$, and high income with GNI per capita above \$12,736 in 2015 according to the World Bank Classification.)

\section{Low Income Countries (GNI of $\$ 4,125$ or less)}

Benin, Burkina Faso, Burundi, Cambodia, the Central African Republic, Chad, Congo Democratic Republic, Ethiopia, the Gambia, Guinea, Guinea-Bissau, Madagascar, Malawi, Mali, Mozambique, Nepal, Niger, Rwanda, Sierra Leone, Tanzania, Togo, Uganda, Zimbabwe.

Armenia, Bangladesh, Bolivia, Cameroon, Cape Verde, Congo Republic, Cote D'Ivoire, Egypt, El Salvador, Georgia, Ghana, Guatemala, Honduras, India, Indonesia, Kenya, Kyrgyz Republic, Lesotho, Mauritania, Morocco, Nigeria, Pakistan, the Philippines, Senegal, Sri Lanka, Sudan, Swaziland, Syria, Tajikistan, Ukraine, Vietnam, Yemen, Zambia.

\section{$\underline{84 \text { High Income Countries (GNI of } \$ 4,126 \text { or more) }}$}

Albania, Angola, Azerbaijan, Belarus, Belize, Bosnia and Herzegovina, Botswana, Brazil, Bulgaria, China, Colombia, Costa Rica, the Dominican Republic, Ecuador, Fiji, Gabon, Iran, Jamaica, Jordan, Kazakhstan, Lebanon, Macedonia FYR, Malaysia, Mauritius, Mexico, Moldova, Mongolia, Montenegro, Namibia, Panama, Paraguay, Peru, Romania, Serbia, South Africa, Suriname, Thailand, Tunisia, Turkey.

Argentina, Australia, Austria, the Bahamas, Barbados, Belgium, Canada, Chile, Croatia, Cyprus, the Czech Republic, Denmark, Estonia, Finland, France, Germany, Greece, Hungary, Iceland, Ireland, Israel, Italy, Japan, Korea Republic, Latvia, Lithuania, 
Luxembourg, Malta, the Netherlands, New Zealand, Norway, Poland, Portugal, Russia, Singapore, Slovakia, Slovenia, Spain, Sweden, Switzerland, Trinidad and Tobago, the United Kingdom, the United States, Uruguay, Venezuela. 